\title{
Hydrogen production from the decomposition of hydrogen-iodide over nanosized nickel-oxide-zirconia catalysts prepared by solution-combustion techniques
}

Amit Singhania ${ }^{\mathrm{a}}$, Venkatesan V. Krishnan ${ }^{\mathrm{a}, \#}$, Ashok N. Bhaskarwar ${ }^{\mathrm{a}}$, Bharat Bhargava ${ }^{\mathrm{b}}$, Damaraju Parvatalu ${ }^{\mathrm{b}}$, Satinath Banerjee ${ }^{\mathrm{b}}$

aDepartment of Chemical Engineering, Indian Institute of Technology Delhi, Hauz Khas, New Delhi 110016, India

${ }^{\mathrm{b}}$ ONGC Energy Centre, $2^{\text {nd }}$ Floor, Core-2, Scope Minar, New Delhi 110092, India

"Corresponding author. Tel.: +91-01126591028; Email: ashoknbhaskarwar@yahoo.co.in (Ashok N. Bhaskarwar)

\# Current Address: Teesside University, School of Science and Engineering, Middlesbrough, TS1 3BA, UK

\section{ABSTRACT}

$\mathrm{NiO} / \mathrm{ZrO}_{2}$ prepared by solution-combustion (SC) showed near equilibrium conversions of HI to $\mathrm{H} 2$ and $\mathrm{I} 2$, at $500-550^{\circ} \mathrm{C}$, at space velocities of $12 \mathrm{hr}^{-1}$, without any performance degradation over 50 hours., , XRD data of the catalyst after $10 \mathrm{~h}$ of reaction were compared with the same after a TPR step in $\mathrm{H}_{2} / \mathrm{Ar}$ on another catalyst sample, to verify $\mathrm{Ni}$ ex-solution. $\mathrm{Ni}$ is clearly visible in the XRD after TPR, although it is not observed under reaction conditions $\left(\mathrm{HI} / \mathrm{H}_{2} \mathrm{O} / \mathrm{N}_{2}\right)$, even after 10 hrs. Instead, onset of monoclinic $\mathrm{ZrO}_{2}$ is observed after reaction, which was not visible after TPR.

Keywords: Hydrogen-iodide decomposition; Hydrogen production; Catalytic activity; Sulfuriodine cycle; Nickel-oxide-Zirconia. 


\section{Introduction}

Hydrogen is a fuel of great importance, as it is widely regarded as the next-generation energy carrier which is clean and can be produced in a renewable manner [1-3] for a huge prospective transportation market, for backup power, and for domestic gas grids. The sulfur-iodine (SI) cycle is considered as a way of efficiently producing large amounts of hydrogen from water, in situations where heat of high quality, e.g. nuclear power plants, is available. Over the past few years, researchers have understood the potential of this cycle [4-12], since it is a feasible, effective, and scalable non-electrolytic pathway for splitting water.

Catalysts reported in literature for hydrogen-iodide decomposition include mostly noble (e.g. Pt) as well as non-noble metals (e.g. Ni), and several bimetallic compositions [13, 14-18]. It is necessary to have a high activity in the desirable temperature window, i.e., $400^{\circ} \mathrm{C}-550^{\circ} \mathrm{C}$ (set primarily by the MoC constraints), achievable by high metal dispersion (nano-sized particles on high surface area supports), and stability against agglomeration and corrosion. In order to achieve high catalyst dispersions, nano-catalysts can be prepared using different techniques such as solgel, precipitation, solution-combustion method (SCM), hydrothermal, reverse micelles, and via sonochemistry [19-23].

Furthermore, due to the high cost of noble metals, it is necessary and also feasible to develop less expensive non-precious metal catalysts. Nickel, for example, has a strong affinity for hydrogen, as observed in hydrocarbon coking, and in hydrogenation. Consequently, it has been used as a catalyst for hydrogenation, for steam reforming, and for condensation of organic compounds [24]. From the practical economic point of view also, nickel is relatively inexpensive, in comparison to the noble metals like platinum and palladium $(\mathrm{Pt}: \$ 960 / \mathrm{lb}, \mathrm{Pd}: \$ 565 / \mathrm{lb}$, and Ni 
: \$3.86/lb) [25]. Nickel catalysts supported on $\gamma$-alumina and ceria were reported as suitable catalysts for hydrogen-iodide decomposition, but they had a poor stability [26, 27]. The National Chemical Laboratory for Industry (NCLI), Japan, reported that the nickel catalyst supported on $\gamma$ alumina was found to spall out of the $\gamma$-alumina support resulting in a loss of catalytic activity for the hydrogen-iodide decomposition reaction [8]. Evidently, catalysts synthesized by techniques like simple impregnation are not adequate for catalytic applications of such corrosive nature.

Regarding the choice of supports, zirconia has been investigated in recent years as a catalyst and support due to its high stability under acidic reaction environments [28]. Furthermore, it has been reported as a better catalyst and support than other materials like $\mathrm{Al}_{2} \mathrm{O}_{3}, \mathrm{TiO}_{2}$, and $\mathrm{SiO}_{2}$ [29] in several reactions such as autothermal reforming of ethanol [30], in solid oxide fuel cells [31], and in hydrogenation reactions [32]. Hence, the combination of $\mathrm{Ni}$ and zirconia is promising as a catalyst for hydrogen-iodide decomposition.

Different methods have been used for the synthesis of nickel-zirconia catalysts, such as sol-gel [21], co-precipitation [22], and impregnation [33]. SCM is yet another method, for the preparation of zirconia based catalysts which has several advantages over the above-mentioned techniques, since it is facile, with very less processing time and is known to produce high-purity products useful for industrial applications. It is a one-step process by which nanomaterials are produced by the disintegration of reaction precursors in quick time. Also, the calcination temperature can be adjusted to obtain nanoparticles and the targeted phase of the oxide support and NiO. The next important issue to address is how to ensure that the catalyst nanoparticles are made resistant to coarsening and corrosion. 
Regarding the stability of metal catalysts on supports, some of the ideas enunciated in the Solid Oxide Fuel Cell anode formulations can be effectively utilized. There is a considerable body of research nowadays on ex-solved Ni particles from solid solutions. Ni is substituted into the Bsite of several perovskites, at very high calcination temperatures [34-39], after which ex-solution occurs under reducing operating conditions. The advantages of ex-solved $\mathrm{Ni}$ are - nanocrystallinity, and therefore high activity, strong adherence to the support and the consequent stability towards sintering, and additionally, coking resistance as demonstrated by Neagu et al. $[38]$.

Interactions of $\mathrm{Ni}$ with $\mathrm{ZrO}_{2}$ have been studied by several authors either as pure $\mathrm{Ni}-\mathrm{ZrO}_{2}$ systems [21, 40, 41] or in ternary systems involving stabilized $\mathrm{ZrO}_{2}$ [42-46], for a range of reactions including - reformation of methane, ethanol, and partial oxidation of methane. The synthetic techniques used in those studies are - Co-precipitation (CP), Pechini's method (Pech), Sol-Gel synthesis (SG), impregnation (solution excess), and Glyco-thermal (GT) method, with the effective calcination temperatures being varied from $250^{\circ} \mathrm{C}$ to $1000^{\circ} \mathrm{C}$. There is a considerable variation in the above literature regarding the structure and reactivity of catalysts as a function of synthesis methods, thereby indicating that the synthetic methods are crucial to the final properties. There are reported evidences in some of the literature that indicate the formation of $\mathrm{NiO}-\mathrm{ZrO}_{2}$ solid solutions at nominal calcination temperatures [21, 40]. Therefore, it stands to reason that it is entirely possible to ex-solve Ni from these solid solutions into a highly dispersed nanoparticulate phase, suitable for the catalysis. We have focused on this idea in this paper wherein we have investigated $\mathrm{SCM}$ as a way to make the $\mathrm{NiO}-\mathrm{ZrO}_{2}$ composite, with the possibility of $\mathrm{Ni}$ nanoparticles' ex-solution under the hydrogen-iodide decomposition atmospheres which are primarily reducing (hydrogen iodide/ water/ nitrogen). Characterization of catalysts by powder 
$\mathrm{XRD}$, and surface area, and its catalytic activity towards hydrogen-iodide decomposition, are presented in this paper, as well.

\section{Experimental}

\subsection{Catalyst preparation}

Zirconyl nitrate hexahydrate and nickel nitrate hexahydrate were used as $\mathrm{Zr}$ and Ni precursors, and urea as fuel. For the synthesis of $\mathrm{NiO}-\mathrm{ZrO}_{2}$ catalysts by $\mathrm{SCM}$, the fuel to metal molar ratio [urea/( $\mathrm{Zr}+\mathrm{Ni})]$ was maintained at 5 with the required $(\mathrm{Zr}+\mathrm{Ni})$ composition, and $\mathrm{NiO}$ mol\% varied from 5 to 15 . Required amounts of nitrates and urea were placed in a $250 \mathrm{~mL}$ beaker with $15-20$ $\mathrm{mL}$ of distilled water. The aforementioned mixture was stirred rigorously until a clear solution resulted, which was followed by insertion of the beaker containing clear solution into a muffle furnace, maintained at $400^{\circ} \mathrm{C}$. Initially, water evaporates and then the ignition of the reactant mixture starts which produces a solid product. This solid material was ground to a fine powder. Finally, it was calcined at $550^{\circ} \mathrm{C}$ for $3 \mathrm{~h}$.

\subsection{Catalyst characterization}

The specific surface area of the synthesized catalysts was determined by BET technique using nitrogen as the adsorbate (Micrometrics, ASAP 2010). XRD data of the solid samples were collected on a Rigaku X-ray diffractometer (DMAX IIIVC) with monochromatic Cu-Ka radiation $(\lambda=1.542 \AA)$. EDX was done on Bruker-AXS system (QuanTax 200). The TEM micrographs of $\mathrm{NiO}-\mathrm{ZrO}_{2}$ catalysts were generated on Tecnai $\mathrm{G}^{2}-20$ Twin (FEI) transmission electron microscope operated at $200 \mathrm{kV}$. 


\subsection{Catalytic experiments}

The heterogeneous gas-phase hydrogen-iodide decomposition reaction was performed under atmospheric pressure in a quartz tube with $16-\mathrm{mm}$ inside diameter. $1 \mathrm{~g}$ of the catalyst sample was loaded into the quartz reactor for activity measurement. The hydrogen-iodide decomposition was performed at different temperatures ranging from $400^{\circ} \mathrm{C}-550^{\circ} \mathrm{C}$. The feedstock was $55 \mathrm{wt} \% \mathrm{HI}$, flowing at a weight-hourly-space velocity (WHSV) of $12.9 \mathrm{~h}^{-1}$ with the help of a micro feeder through a capillary glass inlet. The nitrogen gas was used as a carrier gas and maintained at 40 $\mathrm{ml} / \mathrm{min}$ with the help of a mass flow controller (MFC). Hydrogen iodide, iodine, and water were trapped in a condenser and scrubbers. Only hydrogen and nitrogen were allowed to the pass into gas chromatograph. The product, hydrogen was analyzed by the gas chromatograph (Nucon-5765) which was equipped with a thermal-conductivity detector (TCD) using a Molecular Sieve 5A column.

\section{Results and discussion}

\subsection{Catalyst characterization}

The specific surface area of prepared catalysts measured by BET technique, based on nitrogen adsorption. The surface area is $4.8 \mathrm{~m}^{2} \mathrm{~g}^{-1}$ for UZr5Ni5, $7.9 \mathrm{~m}^{2} \mathrm{~g}^{-1}$ for UZr5Ni10, and $10.6 \mathrm{~m}^{2} \mathrm{~g}^{-1}$ for

UZr5Ni15. The addition of $\mathrm{NiO}$ into the zirconia lattice is expected to cause lattice distortion, which consequently results in an increase in the surface area. The decrease in crystallite size and Commented [KV1]: This is enough; being a small communication, the full details are not needed, particularly if they don't feed into your overall game plan lattice constant values also confirmed the lattice contraction (Table 1). 


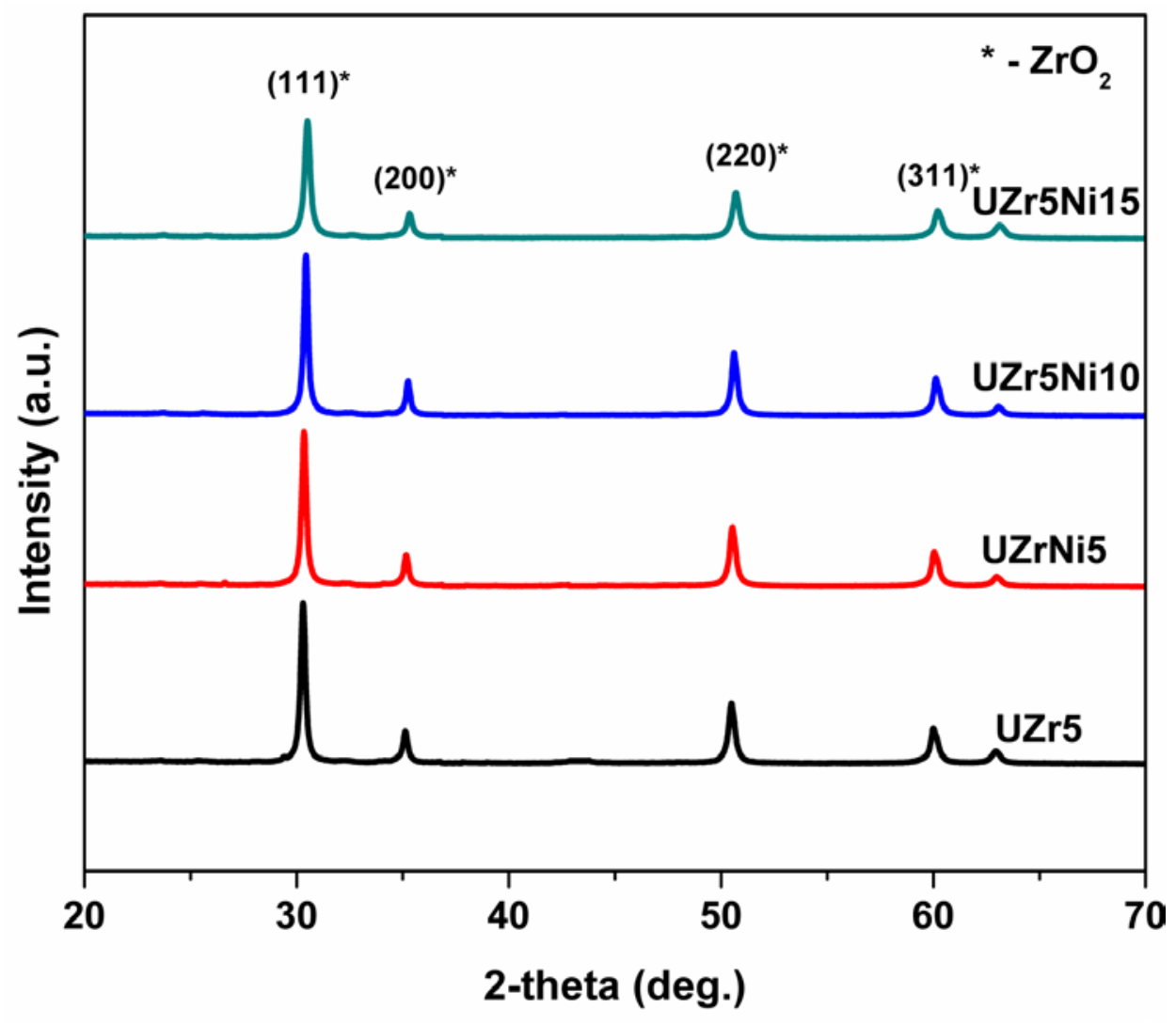

Figure 1. Powder XRD patterns of pure $\mathrm{ZrO}_{2}$ and $\mathrm{NiO}-\mathrm{ZrO}_{2}$ catalysts.

The powder XRD patterns of $\mathrm{NiO}-\mathrm{ZrO}_{2}$ catalysts are shown in Figure 1. XRD patterns showed intense peaks of cubic $\mathrm{ZrO}_{2}$ due to the (111), (200), (220), and (311) planes at $2 \theta=30.3^{\circ}$, $35.14^{\circ}, 50.48^{\circ}$, and $60.2^{\circ}$ which were matched with the reported data (JCPDS-270997). The addition of $\mathrm{NiO}$ into $\mathrm{ZrO}_{2}$ resulted in a single phase, clearly. As shown in Figure 1, with 7 


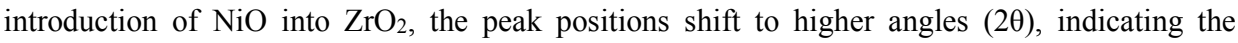
formation of $\mathrm{NiO}-\mathrm{ZrO}_{2}$ solid solutions.

TEM micrographs of UZr5Ni5, UZr5Ni10, and UZr5Ni15 samples are shown in Figures 2(a) to 2(c). TEM analyses of all the samples revealed the individual nanoparticles with regular spherical morphology and with average particle sizes in the range of 25-50 $\mathrm{nm}$. On comparing three different TEM micrographs, it is also observed that the particle size changed upon changing $\mathrm{NiO}$ content. From UZr5Ni5 to UZr5Ni15 (i.e. with an increase in Ni content), the average particle size decreased.

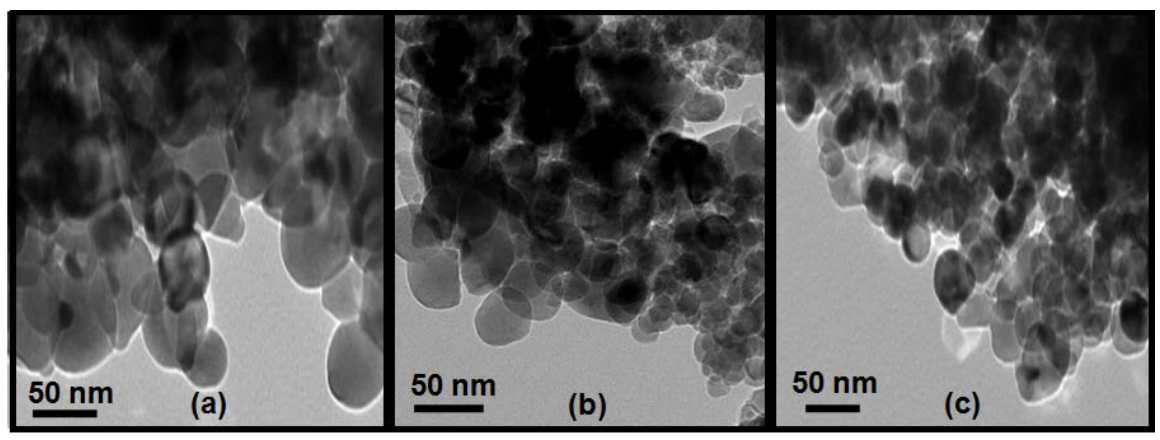

Figure 2. TEM micrographs of (a). UZr5Ni5, (b). UZr5Ni10, and (c). UZr5Ni15.

\subsection{Catalytic activity}

The hydrogen-iodide conversions on $\mathrm{NiO}-\mathrm{ZrO}_{2}$ catalysts at different decomposition temperatures are shown in Figure 3. There was no pre-reduction of the as-prepared (SCM + Calcined) catalyst, as it was heated to the reaction temperature in the inert atmosphere followed by flow of the (hydrogen-iodide)-water-(inert-gas) mixture. 


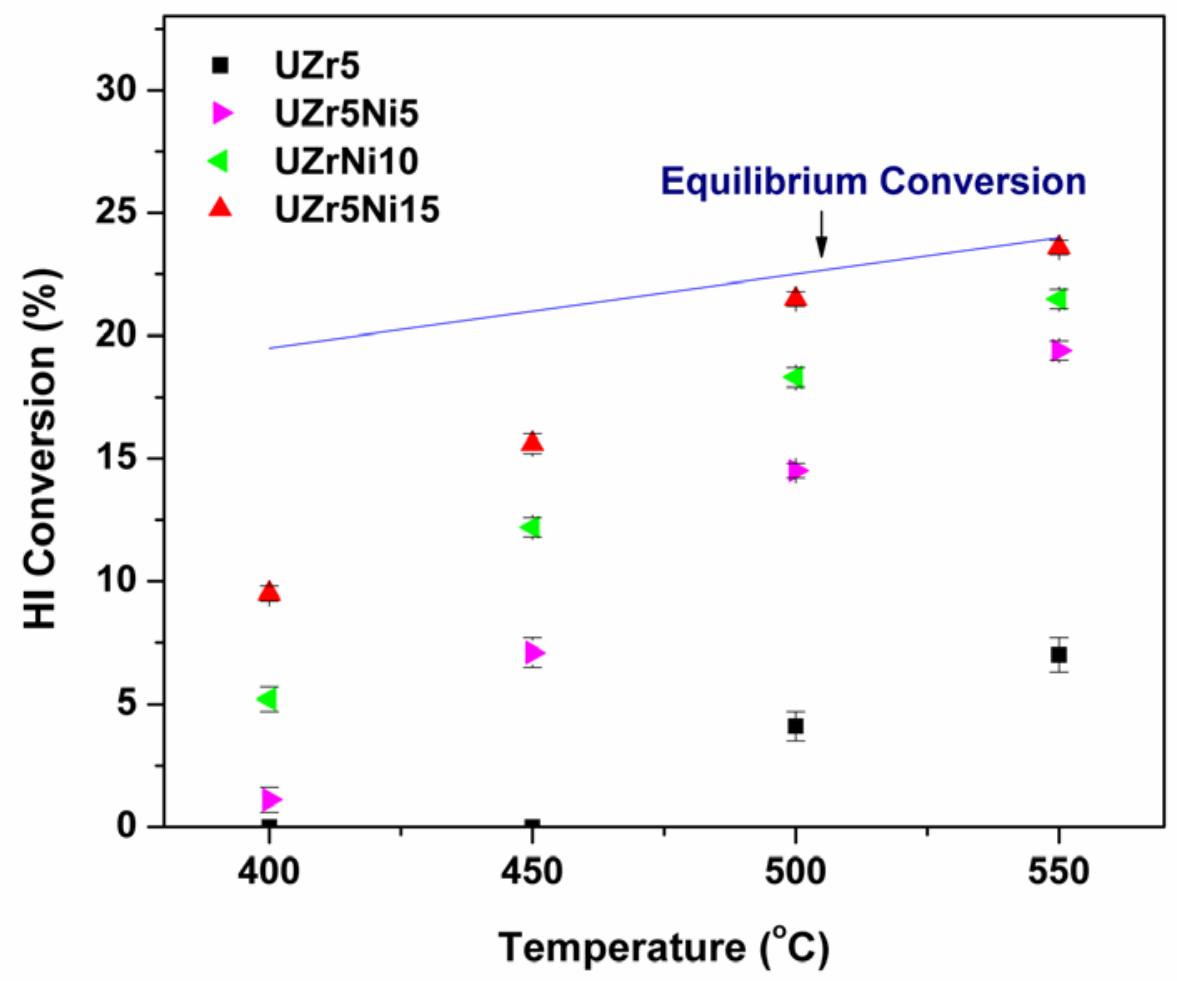

Figure 3. Hydrogen-iodide conversion on $\mathrm{NiO}^{-\mathrm{ZrO}_{2}}$ catalysts at different decomposition temperatures (HI-55 wt\%).

Relative to pure zirconia, $\mathrm{NiO}-\mathrm{ZrO}_{2}$ catalysts showed high conversions, indicating that the metal functionality was playing a major role. UZr5Ni15 gave high hydrogen-iodide conversion of $23.6 \%$ which is very close to the theoretical equilibrium conversion value of $24 \%$ at $550^{\circ} \mathrm{C}$, while a conversion of only $9.5 \%$ is observed at $400^{\circ} \mathrm{C}$. As shown in Figure 3, UZr5Ni15 showed a better catalytic activity than other $\mathrm{NiO}-\mathrm{ZrO}_{2}$ catalysts. In comparison to the hydrogen-iodide conversion of $23.6 \%$ of UZr5Ni15, UZr5Ni10, and UZr5Ni5 showed hydrogen-iodide conversion of $21.5 \%$, 
and $19.8 \%$ at $550^{\circ} \mathrm{C}$. The $\mathrm{UZr} 5$, on the other hand, showed a maximum hydrogen-iodide conversion of only $7.1 \%$ at $550^{\circ} \mathrm{C}$. UZr5Ni15 also showed excellent stability for time-on-stream of $50 \mathrm{~h}$ (Figure S1).

\subsection{Functionality and mechanism}

The catalytic activity for any supported Ni catalyst is usually attributed to the Ni metal, as has been seen frequently in literature for dehydrogenation reactions. However, the real processes surrounding the high stability of the catalytic phase, and the initial solid solution need to be investigated a little further. The original hypothesis was that in the presence of hydrogen iodide/iodine/water mixtures, $\mathrm{NiO}$ can be reduced to $\mathrm{Ni}$, either in part or significantly with time. Since the as-received $\mathrm{NiO}$ has been shown to be in solid solution with $\mathrm{ZrO}_{2}$ (Figure 1), upon reduction, it can ex-solve and be strongly adherent to the support surface as a highly active metallic nano-phase - which could explain its enhanced stability towards the hydrogen-iodide reaction. 


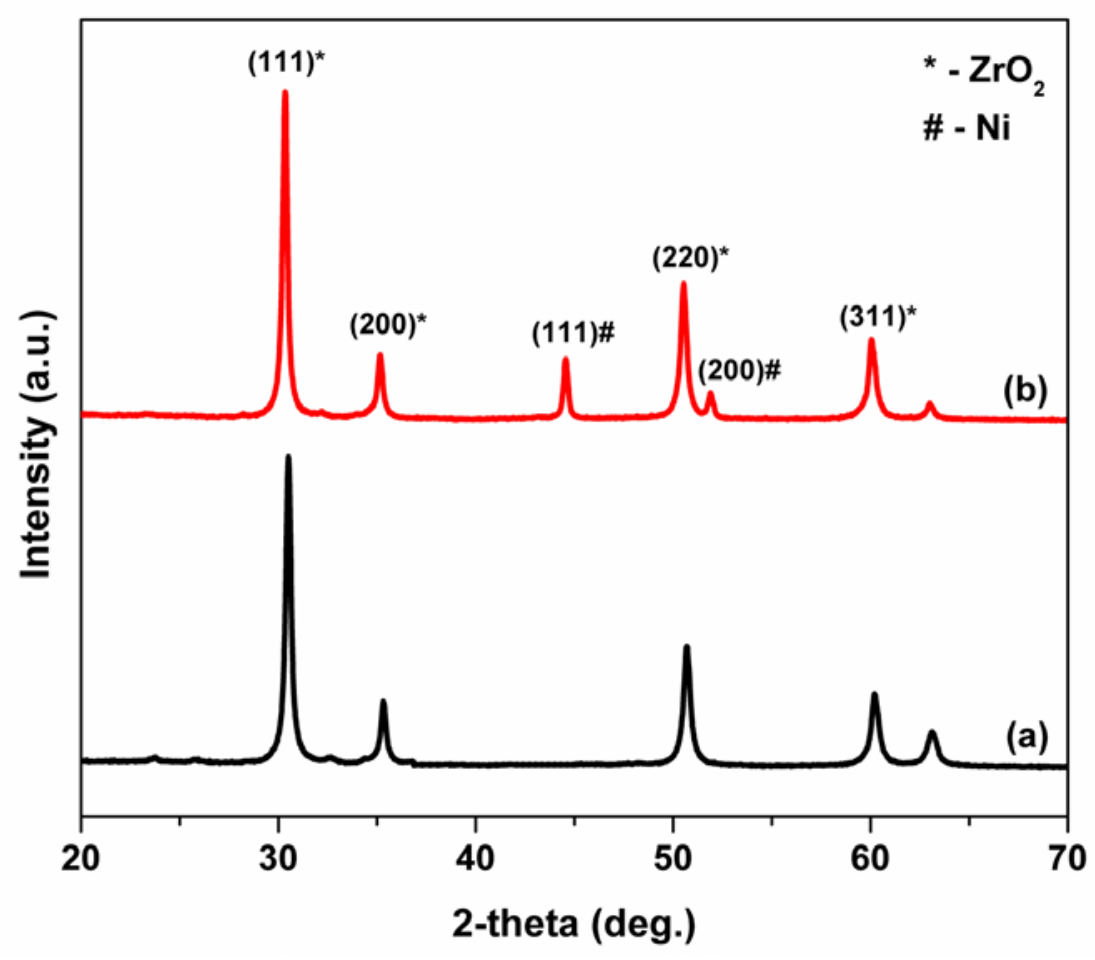

Figure 4. XRD patterns of UZr5Ni15: (a) before TPR, and (b) after TPR.

In order to observe the ex-solution of $\mathrm{Ni}$, TPR experiments were carried out under $\mathrm{H}_{2} / \mathrm{Ar}$ flow which demonstrate clearly that $\mathrm{Ni}$ metal has either ex-solved or has simply been reduced to the Ni metal (if it is a separate oxide phase). This is confirmed by the powder XRD data (Figure 4) and the TPR spectra (Figure 5). 


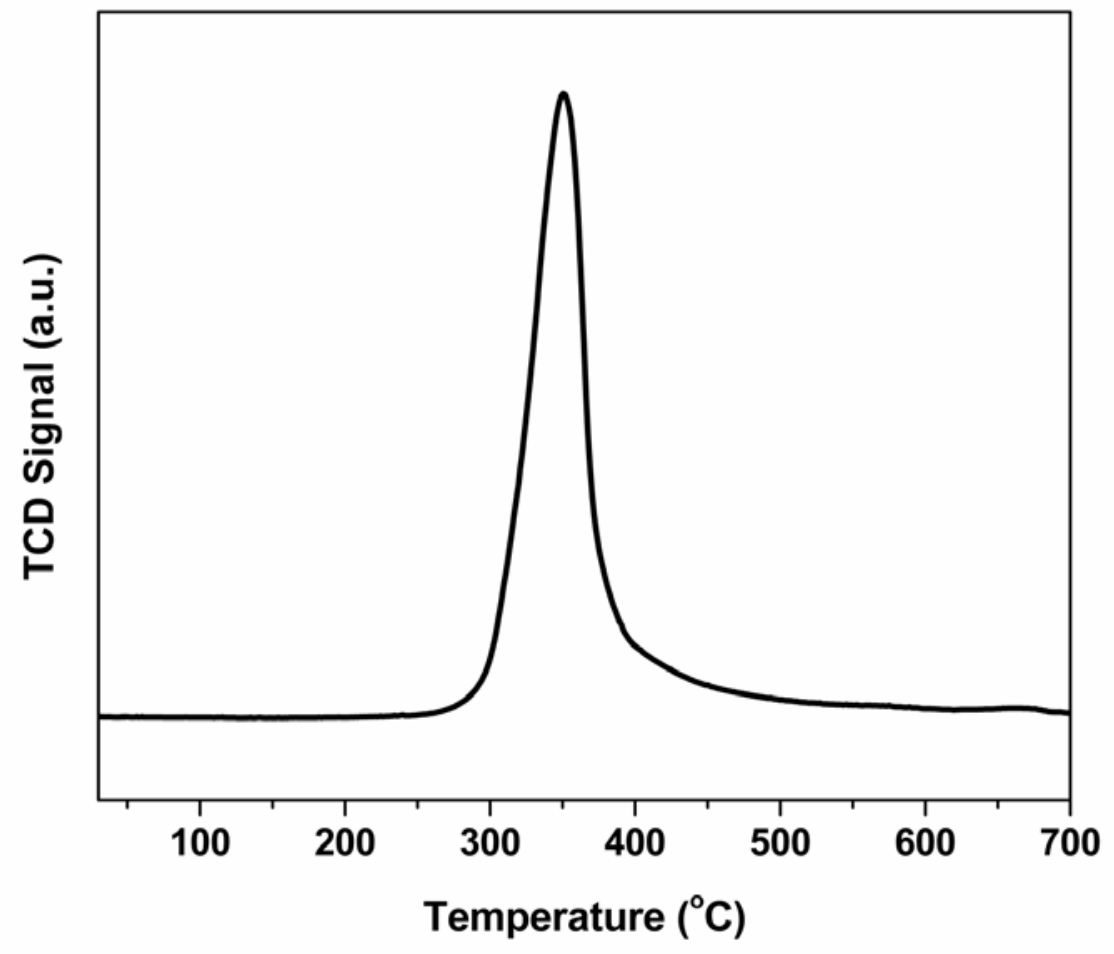

Figure 5. TPR profile of UZr5Ni15.

However, XRD patterns in Figure 6, after $4 \mathrm{~h}$ and $10 \mathrm{~h}$ of reaction are different from those observed after TPR. There are no peaks of $\mathrm{Ni}$, or $\mathrm{NiO}$, even after $10 \mathrm{~h}$ of reaction. Yet, phase changes are visible in the catalyst - the onset of the monoclinic phase is clearly observed. It is likely that the reaction conditions are far less reducing than the under TPR $\left(\mathrm{H}_{2} / \mathrm{Ar}\right)$ flow conditions. It is not clear if there is a metallic phase of $\mathrm{Ni}$ being formed under the reaction conditions. Yet, XRD is usually not sufficient enough to observe very small crystallites of Ni, and as such, if ex-solution did occur, it is not visible. However, phase changes observed from the XRD patterns indicate that $\mathrm{Ni}^{2+}$ ions 
[40].

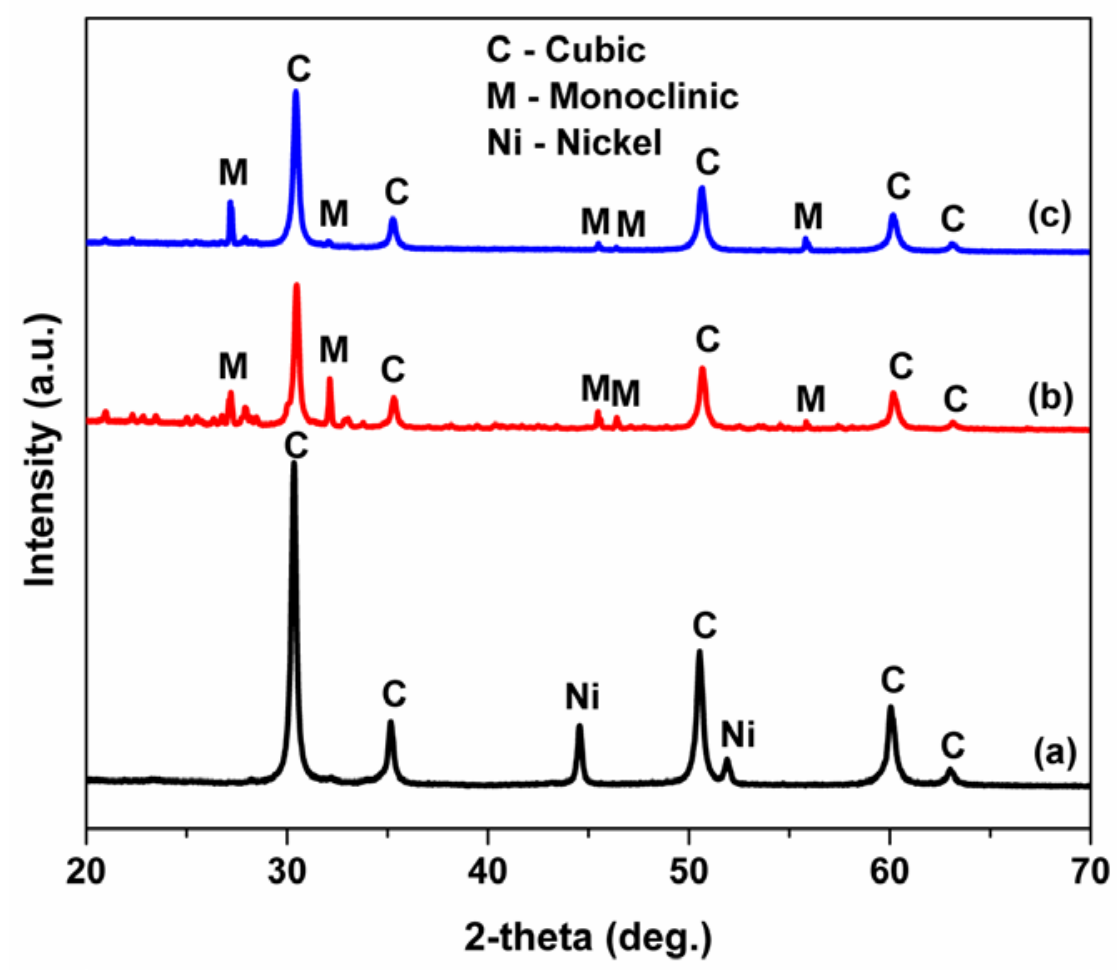

Figure 6. XRD patterns of UZr5Ni15: (a) after TPR, (b) after HI reaction (4 h), and (c) after HI reaction $(10 \mathrm{~h})$.

Yet, the comparative stability of the catalyst for about $50 \mathrm{~h}$, and the high catalytic activity (and its strong dependence on Ni content) are indicative of the formation of an incipient metallic 
phase. Further experiments are in progress, particularly via TEM and higher at Ni doping to decode the reaction mechanism.

\section{Conclusions}

In this study, nano-sized $\mathrm{NiO}-\mathrm{ZrO}_{2}$ catalysts were synthesized by SCM. High catalytic activity was reported, with conversions the almost reaching equilibrium values, at $550^{\circ} \mathrm{C}$, i.e. about $23.6 \%$ per pass at WHSV of $12.9 \mathrm{~h}^{-1}$, at Ni contents of about $15 \mathrm{~mol} \%$, and the catalyst showed a stable performance for up to $50 \mathrm{~h}$. The presence of $\mathrm{NiO}$ in $\mathrm{ZrO}_{2}$ increased the hydrogen iodide-conversion as compared to $\mathrm{ZrO}_{2}$ which indicates the catalytic effect of $\mathrm{Ni} / \mathrm{NiO}$. The reduction to $\mathrm{Ni}$ is clearly visible in TPR, using $\mathrm{H}_{2}$ /Ar mixture, which is confirmed in the XRD analysis of the sample after TPR (emergence of Ni metallic peaks), whereas there is no Ni phase observed in XRD after hydrogen-iodide-decomposition reaction in the hydrogen iodide/water/inert gas flow, even after $10 \mathrm{~h}$. In the latter case, the monoclinic phase of $\mathrm{ZrO}_{2}$ is observed after hydrogen-iodide reaction (not found after TPR analysis). $\mathrm{NiO}-\mathrm{ZrO}_{2}$ has shown itself to be catalytically active and stable for hydrogen-iodide decomposition, although further studies (TEM) are still under process in order to correlate the structure with the catalyst activity.

\section{Acknowledgements}

One of the authors (AS) would like to thank ONGC Energy Centre, India, for providing the research fellowship.

\section{References}

[1] C.J. Winter, Hydrogen energy-abundant, efficient, clean: a debate over the energy-system- 
of-change, Int. J. Hydrogen Energy 34 (2009) S1-52.

[2] P. Moriarty, D. Honnery, Hydrogens's role in an uncertain energy future, Int. J. Hydrogen Energy 34 (2009) 31-39.

[3] K. Maeda, K. Domen, New non-oxide photocatalysts designed for overall water splitting under visible light, J. Phys. Chem. C 111 (2007) 7851-7861.

[4] S. Goldstein, J.M. Borgard, X. Vitart, Upper bound and best estimate of the efficiency of the iodine sulphur-cycle, Int. J. Hydrogen Energy 30 (2005) 619-626.

[5] H.J. Yoon, S.J. Kim, H.C. No, B.J. Lee, E.S. Kim, A thermo-physical model for hydrogeniodide vapor-liquid equilibrium and decomposition behavior in the iodine-sulfur thermochemical water splitting cycle, Int. J. Hydrogen Energy 33 (2008) 5469-5476.

[6] M. Nomura, S. Kasahara, S. Nakao, Silica membrane reactor for the thermochemical iodine-sulfur process to produce hydrogen, Ind. Eng. Chem. Res. 43 (2004) 5874-5879.

[7] Y. Zhang, J. Zhou, Z. Wang, K. Cen, Detailed kinetic modeling and sensitivity analysis of hydrogen iodide decomposition in sulfur-iodine cycle for hydrogen production, Int. J. Hydrogen Energy 33 (2008) 627-632.

[8] D.R. O'Keefe, J.H. Norman, D.G. Williamson, Catalysis research in thermochemical water-splitting processes, Catal. Rev. 22 (1980) 325-369.

[9] Y. Zhang, Z. Wang, J. Zhou, K. Cen, Ceria as a catalyst for hydrogen iodide decomposition in sulfur-iodine cycle for hydrogen production, Int. J. Hydrogen Energy 34 (2009) 1688-1695.

[10] Kubo S, Nakajima H, Kasahara S, Higashi S, Masaki T, Abe H, Onuki K. A demonstration study on a closed-cycle hydrogen production by the thermochemical water-splitting iodinesulfur process. Nucl Eng Des 2004;233:347-54. 
[11] Roth M, Knoche KF. Thermochemical water splitting through direct HI-decomposition from $\mathrm{H}_{2} \mathrm{O} / \mathrm{HI} / \mathrm{I}_{2}$ solutions. Int J Hydrogen Energy 1989;14(8):545-9.

[12] Funk JE. Thermochemical hydrogen production: past and present. Int J Hydrogen Energy 2001;26(3):185-90.

[13] Singhania A, Krishnan VV, Bhaskarwar AN, Bhargava B, Parvatalu D, Banerjee S. Catalytic performance of bimetallic Ni-Pt nanoparticles supported on activated carbon, gamma-alumina, zirconia, and ceria for hydrogen production in sulfur-iodine thermochemical cycle. Int J Hydrogen Energy 2016;41(25):10538-46.

[14] Chen Y, Wang Z, Zhang Y, Zhou Z, Cen K. Platinum-ceria-zirconia catalysts for hydrogen production in sulfur-iodine cycle. Int J Hydrogen Energy 2010;35(2):445-51.

[15] Wang ZC, Wang LJ, Zhang P, Chen SZ, Xu JM, Chen J. Effect of preparation methods on Pt/alumina catalysts for the hydrogen iodide catalytic decomposition. Chin Chem Lett 2009;20(1):102-5.

[16] Zhang Y, Zhou J, Chen Y, Wang Z, Liu J, Cen K. Hydrogen iodide decomposition over nickel-ceria catalysts for hydrogen production in the sulfur-iodine cycle. Int J Hydrogen Energy 2008;33(20):5477-83.

[17] Singhania A, Bhaskarwar AN, Bhargava B, Parvatalu D, Banerjee S, Prabhu BN, Bhardwaj A, Thomas NJ, Kale DM. IN Patent 2259/DEL/2014 2014.

[18] Singhania A, Bhaskarwar AN, Bhargava B, Parvatalu D, Banerjee S, Prabhu BN, Bhardwaj A, Thomas NJ, Kale DM. IN Patent 2308/DEL/2014 2014.

[19] Niemeyer D, Williams DE, Smith P, Pratt KFE, Slater B, Richard C, Catlow C, Stoneham AM. Experimental and computational study of the gas-sensor behaviour and surface chemistry of the solid-solution $\mathrm{Cr}_{2-\mathrm{x}} \mathrm{Ti}_{\mathrm{x}} \mathrm{O}_{3}(\mathrm{x} \leq 0.5)$. J Mater Chem 2002;12:667-75. 
[20] Mapa M, Gopinath CS. Combustion synthesis of triangular and multifunctional $\mathrm{ZnO}_{1-\mathrm{X}} \mathrm{N}_{\mathrm{X}}$ ( $x \leq 0.15$ ) materials. Chem Mater 2009;21:351-9.

[21] Dongare MK, Malshe K, Gopinath CS, Murwani, IK, Kemnitz E. Oxidation activity and ${ }^{18} \mathrm{O}$-isotope exchange behavior of nickel oxide-stabilized cubic zirconia. J Catal 2004;222(1):80-6.

[22] Songali L, Ruisong G, Jinyou L, Yuru C, Liu W. Synthesis of NiO- $\mathrm{ZrO}_{2}$ powders for solid oxide fuel cells. Ceramics Int 2003;29(8)883-6.

[23] Teng F, Xu P, Tian Z, Xiong G, Xu Y, Xu Z, Lin L. Synthesis of the high-surface-area $\mathrm{Ce}_{\mathrm{x}} \mathrm{Ba}_{1-\mathrm{x}} \mathrm{MnAl}_{11} \mathrm{O}_{\mathrm{y}}$ catalyst in reverse microemulsions using inexpensive inorganic salts as precursors. Green Chem 2005;7:493-9.

[24] Adkins H, Cramer HI. The use of nickel as a catalyst for hydrogenation. J Am Chem Soc 1930;52(11):4349-58.

[25] www.icmj.com/current-metal-prices.php.

[26] Favuzza P, Felici C, Lanchi M, Liberatore R, Mazzocchia CV, Spadoni A,Tarquini P, Tito AC. Decomposition of hydrogen iodide in the S-I thermochemical cycle over Ni catalyst systems. Int J Hydrogen Energy 2009;34(9):4049-56.

[27] Zhang Y, Wang Z, Zhou J, Liu J, Cen K. Catalytic decomposition of hydrogen iodide over pre-treated $\mathrm{Ni} / \mathrm{CeO}_{2}$ catalysts for hydrogen production in the sulfur-iodine cycle. Int $\mathrm{J}$ Hydrogen Energy 2009;34(21):8792-8.

[28] Tyagi D, Varma S, Bharadwaj SR. Pt/Zirconia catalyst for hydrogen generation from HI decomposition reaction of S-I cycle. Int J Energy Res 2015;39(4):484-93.

[29] Sivakumar M, Gedanken A, Zhong Z, Chen L. Acoustic cavitation-an efficient energetic tool to synthesize nanosized $\mathrm{CuO}-\mathrm{ZrO}_{2}$ catalystswith a mesoporous distribution. New $\mathrm{J}$ 
Chem 2006;30(1):102-7.

[30] Youn MH, Seo JG, Song IK. Hydrogen production by auto-thermal reforming of ethanol over nickel catalyst supported on metal oxide-stabilized zirconia. Int J hydrogen Energy 2010;35(8):3490-8.

[31] Wang W, Su C, Zheng T, Liao M, Shao Z. Nickel zirconia cerate cermet for catalytic partial oxidation of ethanol in a solid oxide fuel cell system. Int $\mathrm{J}$ Hydrogen Energy 2012;37(10):8603-12.

[32] Kondo J, Domen K, Maryya KI, Onishi T. Infrared studies of ethane hydrogenation over $\mathrm{ZrO}_{2}$. Part 1.-Ethene adsorption. J Chem Soc Faraday Trans 1990;86(17):3021-6.

[33] Rezaei M, Alavi SM, Sahebdelfar S, Bai P, Liu X, Yan ZF. $\mathrm{CO}_{2}$ reforming of $\mathrm{CH}_{4}$ over nanocrystalline zirconia-supported nickel catalysts. Appl Catal B Environ 2008;77(34):346-54.

[34] Adijanto L, Padmanabhan VB, Gorte RJ, Vohs JM. Polarization-induced hysteresis in CuCo-doped rare earth vanadates SOFC anodes. J Electrochem Soc 2012;159:F751-6.

[35] Arrive C, Delahaye T, Joubert O, Gauthier G. Exsolution of nickel nanoparticles at the surface of a conducting titanate as potential hydrogen electrode material for solid oxide electrochemical cells. J Power Sources 2013;223:341-8.

[36] Park BH, Choi GM. Ex-solution of nickel nanoparticles in a $\mathrm{La}_{0.2} \mathrm{Sr}_{0.8} \mathrm{Ti}_{1-\mathrm{x}} \mathrm{Ni}_{\mathrm{x}} \mathrm{O}_{3-\delta}$ alternative anode for solid oxide fuel cell. Solid State Ionics 2014;262:345-8.

[37] Sun Y, Li J, Zeng Y, Amirkhiz BS, Wang M, Behnamian Y, Luo J. A-site deficient perovskite: the parent for in situ exsolution of highly active, regenerable nanoparticles as SOFC anodes. J Mater Chem A 2015;3:11048-55.

[38] Neagu D, Oh TS, Miller DN, Menard H, Bukhari SM, Gamble SR, Gorte RJ, Vohs JM, 
Irvine JTS. Nano-socketed nickel particles with enhanced coking resistance grown in situ by redox exsolution. Nature Comm 2015;6:1-8.

[39] Papargyriou D, Irvine JTS. Nickel nanocatalyst exsolution from ( $\mathrm{La}, \mathrm{Sr})(\mathrm{Cr}, \mathrm{M}, \mathrm{Ni}) \mathrm{O}_{3}$ $(\mathrm{M}=\mathrm{Mn}, \mathrm{Fe})$ perovskites for the fuel oxidation layer of oxygen transport membranes. Solid State Ionics 2016;288:120-3.

[40] Elshazly ES, Abdelal OAA. Nickel stabilized zirconia for SOFCs: synthesis and characterization. Int J Metallurgical Eng 2012;1(6):130-4.

[41] Pompeo F, Nichio NN, Ferretti OA, Resasco D. Study of Ni catalysts on different supports to obtain synthesis gas. Int J Hydrogen Energy 2005;30:1399-405.

[42] Takeguchi T, Furukawa SN, Inoue M. Hydrogen spillover from $\mathrm{NiO}$ to the large surface area $\mathrm{CeO}_{2}-\mathrm{ZrO}_{2}$ solid solutions and activity of the $\mathrm{NiO} / \mathrm{CeO}_{2}-\mathrm{ZrO}_{2}$ catalysts for partial oxidation of methane. J Catal 2001;202:14-24.

[43] Deng X, Sun J, Yu S, Xi J, Zhu W, Qiu X. Steam reforming of ethanol for hydrogen production over $\mathrm{NiO} / \mathrm{ZnO} / \mathrm{ZrO}_{2}$ catalysts. Int J Hydrogen Energy 2008;33:1008-13.

[44] Asencios YJO, Bellido JDA, Assaf EM. Synthesis of NiO-MgO- $\mathrm{ZrO}_{2}$ catalysts and their performance in reforming of model biogas. Appl Catal A Gen 2011;397:138-44.

[45] Takano H, Shinomiya H, Izumiya K, Kumagai N, Habazaki H, Hashimoto K. $\mathrm{CO}_{2}$ methanation of $\mathrm{Ni}$ catalysts supported on tetragonal $\mathrm{ZrO}_{2}$ doped with $\mathrm{Ca}^{2+}$ and $\mathrm{Ni}^{2+}$ ions. Int J Hydrogen Energy 2015;40:8347-55.

[46] Takano H, Kirihata Y, Izumiya K, Kumagai N, Habazaki H, Hashimoto K. Highly active $\mathrm{Ni} / \mathrm{Y}$-doped $\mathrm{ZrO}_{2}$ catalysts for $\mathrm{CO}_{2}$ methanation. Appl Surf Sci 2015; In Press, Corrected Proof. 
